\title{
Before Minimally Invasive Parathyroidectomy in Patients with Primary Hyperparathyroidism Ultrasonography Accompanied by Methylene Blue Staining: A Case Guided Review
}

\author{
Primer Hiperparatiroidizmli Hastada Minimal Invaziv \\ Paratiroidektomi Oncesi Ultrasonografi Eşliğinde Metilen Mavisi \\ ile Boyama Yönteminin Bir Olgu Eşliğinde Değerlendirilmesi
}

(1) Aykut Soyder ${ }^{1}$, (1) Mustafa Ünübol ${ }^{2}$, (1) Eyüp Murat Yılmaz ${ }^{1}$, (1) Engin Güney ${ }^{2}$

${ }^{1}$ Aydın Adnan Menderes University Faculty of Medicine, Department of General Surgery, Aydın, Turkey

${ }^{2}$ Aydın Adnan Menderes University Faculty of Medicine, Department of Endocrinology and Metabolic Diseases, Aydın, Turkey

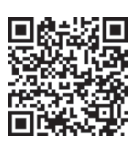

Keywords

Parathyroid adenoma, methylene blue, minimally invasive parathyroidectomy

Anahtar Kelimeler

Paratiroid adenom, metilen mavisi, minimal invaziv paratiroidektomi

Received/Geliş Tarihi : 30.12 .2014

Accepted/Kabul Tarihi : 08.10.2015

doi:10.4274/meandros.galenos.2015.2042

Address for Correspondence/Yazışma Adresi: Eyüp Murat Yılmaz,

Aydın Adnan Menderes University Faculty of Medicine, Department of General Surgery,

Aydın, Turkey

Phone : +90 2564441256

E-mail :drmyilmaz80@gmail.com

ORCID ID: orcid.org/ 0000-0002-0808-5067

(C) Meandros Medical and Dental Journal, Published by Galenos Publishing House.

This is article distributed under the terms of the Creative Commons Attribution NonCommercial 4.0

International Licence (CC BY-NC 4.0).

\begin{abstract}
Primary hyperparathyroidism is an endocrine disease that leads to the excessive secretion of the parathyroid hormone. In most patients with an underlying disease of parathyroid adenoma, its excision usually provides the definitive treatment. However, localization in surgery can be difficult due to the wide anatomic location of the parathyroid gland caused by changes in the shape and number. Especially parathyroidectomy had neck surgery in a patient poses a problem for endocrine surgeons still important. Determining the localization among these patients is more difficult. Compared to patients who have previously undergone neck surgery, a higher number of recurrent laryngeal nerve injuries and an increased incidence of postoperative hypocalcemia are noted, and a lower number of cure rates exist. In this case, we evaluated preoperative ultrasound-guided parathyroid adenoma lesions detected by the methylene blue stain, making painting easier during the operation and the postoperative treatment successful.
\end{abstract}

Öz

Primer hiperparatiroidizm, parathormonun aşırı sekresyonu ile giden endokrin bir hastalıktır. Hastalarının çoğunda altta yatan neden paratiroid adenomdur. Paratirod adenomun cerrahi eksizyonu genellikle kesin tedavisini sağlamaktadır. Paratiroid bezlerinin geniş anatomik konumu, şekil ve sayısındaki değişiklik sebebiyle cerrahide bazı lokalizasyon bulma zorluklarına sebep olabilmektedir. Özellikle boyun cerrahisi geçirmiş bir hastada paratiroidektomi, endokrin cerrah için halen önemli bir sorun oluşturmaktadır. Bu hastalarda lokalizasyonu saptamak daha güçtür. Daha önce boyun cerrahisi geçirmemiş hastalara göre reküren laringeal sinir hasarı ve postoperatif hipokalsemi görülme artışı daha fazla olup, daha düşük kür oranları mevcuttur. Biz bu olguda preoperatif ultrasonografi eşliğinde paratiroid adenom düşünülen lezyona metilen mavisi ile boyama yapıp operasyon sırasında lezyonun kolay tespit edilebilirliğini ve postoperatif tedavi başarısını değerlendirdik. 


\section{Introduction}

Primary hyperparathyroidism is an endocrine disease characterized by excessive secretion of parathyroid hormone (PTH) beyond the physiological control of negative feedback mechanisms. Parathyroid adenoma is the underlying cause in most patients (1). Surgical excision of parathyroid adenoma usually provides definitive treatment (2). Minimally invasive parathyroidectomy (MIP) has started to be performed frequently in the treatment of parathyroid adenoma in recent years and is now preferred in the first place. Due to the wide anatomical location, shape, and number of parathyroid glands, it may cause some difficulties in their localization during surgery $(3,4)$. Parathyroidectomy is still an important problem for the endocrine surgeon, especially in a patient who has undergone neck surgery (5). Localization is more difficult in these patients. The incidence of recurrent laryngeal nerve injury and postoperative hypocalcemia is higher and there are lower cure rates compared to patients who have not undergone neck surgery (5-7). Localization of adenoma by preoperative and intraoperative imaging is very important to reduce the risk of postoperative complications (5). Methods such as neck ultrasonography (USG), Tc-99m sestamibi scintigraphy, magnetic resonance imaging (MRI), computed tomography, and PTH measurement in fineneedle aspiration are routinely used for localization of parathyroid in the preoperative period. Meanwhile, methods such as intraoperative gamma probe use and PTH measurement may be applied to increase the chance of success in parathyroidectomy (8).

Preoperative USG-guided methylene blue staining protocol is a new method and is not routinely used. Successful results have been reported for the detection of the intraoperative lesion in several case series in the literature $(5,9)$. In this case, we stained the lesion, which is thought to be parathyroid adenoma accompanied by preoperative USG, with methylene blue and evaluated the easy detectability of the lesion during MIP and the success of postoperative treatment. We aimed to share our first experience with this newly used method, which has been reported at a limited number of case levels in the literature with this case.

\section{Case Report}

A 60-year-old female patient underwent a subtotal thyroidectomy approximately 12 years ago with the diagnosis of nodular goiter. No dermatological pathology was found in the patient admitted to the dermatology outpatient clinic with the complaint of pruritus. In the examinations, serum calcium (Ca) level was determined to be $10.4 \mathrm{mg} / \mathrm{dL}$ (8.5-10.2 mg/ $\mathrm{dL}$ ) and the patient was directed accordingly. The patient's serum PTH level was found to be $215 \mathrm{pg} /$ $\mathrm{mL}(16-88 \mathrm{pg} / \mathrm{mL})$, serum albumin level $4.5 \mathrm{~g} / \mathrm{dL}$, and serum phosphorus level $3.5 \mathrm{mg} / \mathrm{dL}(2.3-4.7 \mathrm{mg} / \mathrm{dL})$. Neck USG of the patient, who was thought to have primary hyperparathyroidism, revealed a hypoechoic, smooth-bound lesion in the right lobe lower pole of the thyroid gland, approximately $18 \times 14 \times 10 \mathrm{~mm}$ in diameter, consistent with parathyroid adenoma. Parathyroid Tc-99m sestamibi showed an increase in activity consistent with parathyroid adenoma in the right lobe lower pole of the thyroid gland. Surgical indications were evaluated in the patient with asymptomatic primary hyperparathyroidism. The patient had no history of recurrent renal calculi. Serum creatinine was $0.8 \mathrm{mg} / \mathrm{dL}$. In bone densitometry (Dual-energy X-ray absorptiometry), lumbar total t-score was found to be -3.2 , and z-score -3. Calcium excretion in 24-hour urine was $325 \mathrm{mg} /$ day. Serum $25(\mathrm{OH})$ vitamin D level was $26.8 \mathrm{ng} / \mathrm{mL}$. It was planned to perform MIP because the patient was determined to have parathyroid adenoma on imaging and had surgical indications of asymptomatic primary hyperparathyroidism (10). The patient was informed about the operation and her informed consent was obtained. It was planned to preoperatively apply methylene blue to the lesion observed in the lower pole of the right lobe in the endocrinology outpatient clinic under USG. The lesion, which is thought to be parathyroid adenoma, was determined by USG and cleaned with isopropyl alcohol. 4-cc saline solution and 1\% 1-cc methylene blue solution were mixed into a 5-cc sterile injector and diluted (5). It was withdrawn to a 1-cc sterile injector. Approximately 0.3-cc methylene blue solution prepared by diluting with a 23-gauge sterile needle was injected into the lesion under USG. The patient was taken to the operating room about 20 minutes later. MIP was applied. A lesion consistent with adenoma stained with methylene blue was found and excised (Figure 1,2). It was sent to the frozen section and the procedure was terminated and the patient was taken to the inpatient ward when the frozen result was found to be compatible with the 


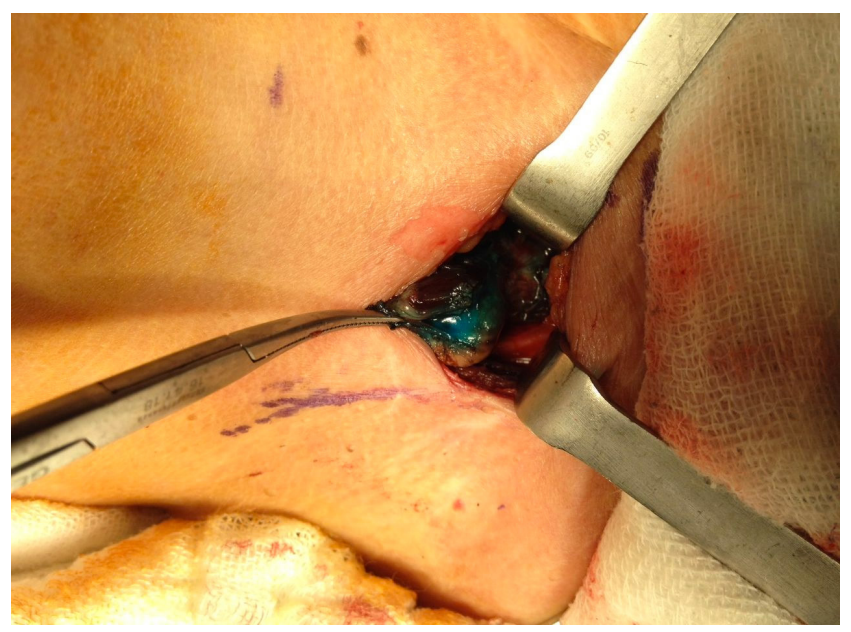

Figure 1. Parathyroid adenoma stained with methylene blue

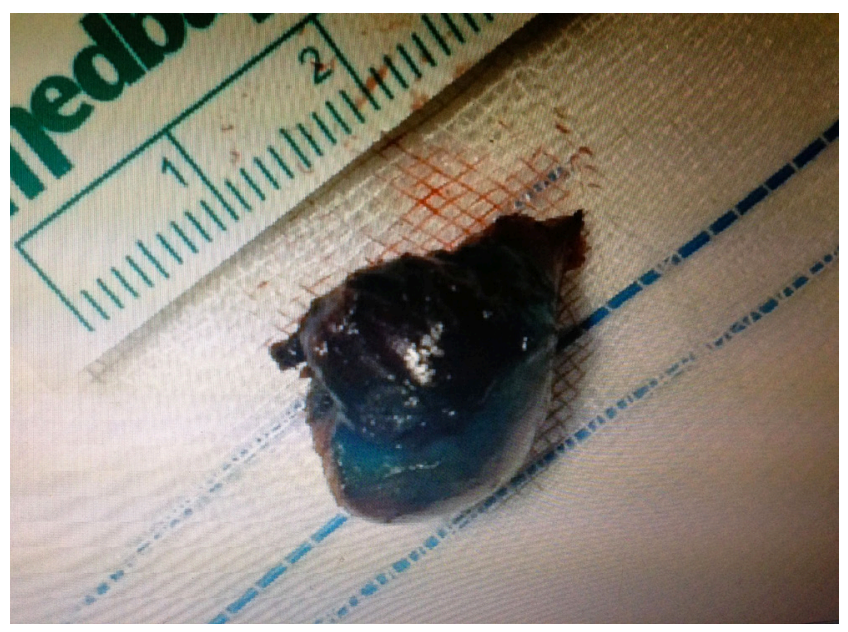

Figure 2. He appearance of blue stained adenoma after excision

parathyroid gland. Serum Ca on the first postoperative day: $9.3 \mathrm{mg} / \mathrm{dL}$ and PTH: $18 \mathrm{pg} / \mathrm{mL}$, the patient was discharged in accordance with recommendations. The pathology result was found to be a parathyroid adenoma. No postoperative complications developed during the follow-up. CA and PTH values of the patient at the postoperative $6^{\text {th }}$ month were in the normal range and no lesion was observed in parathyroid USG. The patient is in a smooth follow-up.

\section{Discussion}

The procedure to be followed for operation in primary hyperparathyroidism has changed over the years; MIP is now accepted as the gold standard whereas neck exploration was popular before
$(3,4)$. The operation may be performed on a single parathyroid gland, sometimes under local anesthesia, in a shorter period of surgery with minimally invasive intervention. This shortens the duration of hospital stay of the patient and provides better cosmetic and wound healing results $(11,12)$. However, the localization of the pathological gland or adenoma should be performed very well in the preoperative period in order for MIP to be performed well (13). Neck USG and Tc-99m sestamibi are recommended in all patients with primary hyperparathyroidism. Neck MRI and $\mathrm{CT}$ are among the methods used in cases where the lesion cannot be detected $(8,13)$. Sestamibi scans may show false-negative or false-positive results due to the size and location of the affected parathyroid lesion and in the presence of thyroid nodule. In this case, PTH measurement may be used in the material aspirated by fine-needle aspiration made to the nodule under USG $(14,15)$. Apart from preoperative localization studies, various intraoperative methods are also used to detect the lesion easily during the operation, to shorten the operative time, and to reduce the risk of complications (8). Localization of parathyroid gland using intraoperative gamma probe is one of the intraoperative methods that may facilitate the procedure (11). However, the absence of gamma probes in every center limits its use.

Various applications have been tried in parathyroid surgery apart from routine methods. In particular, intraoperative intravenous methylene blue infusion was used to detect abnormal parathyroid glands and it yielded successful results $(16,17)$. In a study by Van Der Vorst et al. (16), 12 patients were given $0.5 \mathrm{mg} /$ $\mathrm{kg}$ methylene blue intravenously and parathyroid adenoma was found to retain methylene blue. In the same study, they say that the parathyroid tissue stained and preoperative imaging methods are correlated. In a similar study, Bewick and Pfleiderer (17) operated on 98 patients with primary hyperparathyroidism under methylene blue infusion $(3.5 \mathrm{mg} / \mathrm{kg})$. Positive staining was detected in $78.6 \%$ of the patients. In conclusion, it was emphasized that intraoperative methylene blue infusion has similar sensitivity rates and is an effective method for detecting abnormal parathyroid glands by preoperative USG and radionuclide scan. However, it was reported that patients receiving intravenous methylene blue may have confusion, status epilepticus, metabolic encephalopathy, and anaphylactic shock (18). 
Candell etal. (5) performed preoperative methylene blue under USG on 9 patients who had previously undergone neck surgery and parathyroidectomy due to primary hyperparathyroidism. They found a decrease of more than $50 \%$ in intraoperative PTH measurements after resection. Primary hyperparathyroidism was reported to have been successfully treated in all patients. It was suggested that methylene blue injection may be a safe and effective method for localizing abnormal parathyroid tissue in patients who have undergone neck surgery and are planned to undergo parathyroidectomy. In a study by Ryan and Orloff (9), 20 tumors (15 papillary thyroid cancer lymph node metastasis, 2 Hurthle cell carcinoma, 1 medullary thyroid cancer, 1 lymphoma, and 1 parathyroid adenoma) were stained with methylene blue prior to the operation. As a result, they suggested that methylene blue stain injection under USG was successful in guiding the surgeon to the appropriate location for tumor resection, thus possibly beneficial for reducing the duration of surgery, reducing sampling error, and morbidity. We performed staining with methylene blue under preoperative USG on our patient, who we decided to MIP for primary hyperparathyroidism and detected a lesion compatible with parathyroid adenoma in USG and Tc-99m sestamibi. The stain we applied to the lesion in the preoperative period was seen to be retained by the tissue about 20 minutes after the procedure. We found that abnormal parathyroid tissue stained with methylene blue was consistent with preoperative imaging methods. Thus, we ensured that the lesion stained with methylene blue before the operation was easily found and excised during MIP. During this time, we observed that the stain did not spread to different tissues and could directly help us to localize. This helped to find abnormal parathyroid tissue easily during surgery and to complete the surgery in a shorter time. This practice was consistent with the results of a limited number of similar cases reported in the literature $(5,9)$.

Permanent recurrent laryngeal nerve paralysis and permanent hypoparathyroidism are seen in 3-10\% of patients after parathyroidectomy in patients who underwent neck surgery (6). Candell et al. (5) reported transient recurrent laryngeal nerve paralysis in only 1 of 9 patients who underwent parathyroidectomy with methylene blue injection. No complications were detected after methylene blue staining and MIP in our case. However, Candell et al. (5) did not observe an increase in recurrent laryngeal nerve paralysis in the application on 9 patients although it is thought that overspreading methylene blue out of the lesion during staining or applying it incorrectly may make it difficult to find the recurrent laryngeal nerve during the operation.

The lesion in the parathyroid gland is entered using a fine needle during preoperative methylene blue application. A potential risk of fine-needle aspiration to parathyroid tissue is the seeding of cells due to rupture in the gland capsule (seeding-parathyromatosis) and the recurrence of adenoma (19). However, the fineneedle aspiration method is used more frequently in preoperative PTH measurement procedures in the lesion suggesting parathyroid adenoma. In the series evaluating these cases, recurrence of primary hyperparathyroidism after fine-needle aspiration has not been reported $(14,15,19,20)$.

There is also a suspicion that fine-needle aspiration into parathyroid tissue may damage the capsule and cause problems in terms of parathyroid carcinoma and adenoma in tissue diagnosis. Parathyroid carcinoma is a very rare neoplasm and accounts for less than $1 \%$ of cases with primary hyperparathyroidism (21). In the article of Ünübol et al. (22), parathyroid carcinoma was detected in only 1 case out of 86 cases with primary hyperparathyroidism operated between 2007-2011. Today, histopathological criteria published by Schantz and Castleman (23) are still used for the fairly rare parathyroid carcinoma. Parathyroid carcinoma is diagnosed with tumor cell lobules and leaves separated by dense fibrous bands, mitotic activity, necrosis, capsule, and vascular invasion in these criteria. Therefore, we do not think that deterioration of capsule integrity alone during the procedure will pose a problem histopathologically in the differentiation of adenoma/carcinoma. Such a problem has not been reported in studies where fine needle aspiration into parathyroid was performed $(14,15,19,20)$.

In this case, the application of localized methylene blue under USG helped us to easily recognize and reach the intraoperatively stained tissue, shorten the operative time, and implement a successful MIP without complications. In conclusion, we believe that the determination of abnormal parathyroid lesion 
accompanied by USG in the preoperative period and the application of methylene blue will help intraoperative localization safely and effectively in accordance with the limited number of case results in the literature. However, we think that this application should be supported by a larger series and further studies.

\section{Ethics}

Informed Consent: The patient was informed about the operation and her informed consent was obtained.

Peer-review: Externally and internally peerreviewed.

\section{Authorship Contributions}

Concept: A.S., E.G., Design: E.M.Y., M.Ü., Supervision: M.Ü., E.M.Y., Fundings: E.M.Y., M.Ü., A.S., Matererials: A.S., M.Ü., EM.Y., Data Collection or Processing: M.Ü., E.G., Analysis or Interpretation: M.Ü., E.M.Y., Literature Search: A.S., M.Ü., Critical Review: E.G., A.S., Writing: M.Ü., E.M.Y.

Conflict of Interest: There is no conflict of interest between the authors.

Financial Disclosure: No financial support has been received from anywhere for this article.

\section{References}

1. Johnson JT, Rosen CA. Bailey's Head \& Surgery Otolaryngology, Volume 2. 5th edition. Baltimore MD: Lippincott Williams \& Wilkins; 2013.

2. Williams BA, Trites JR, Taylor SM, Bullock MJ, Hart RD. Surgical management of primary hyperparathyroidism in Canada. J Otolaryngol Head Neck Surg 2014; 43: 44.

3. Lew JI, Solorzano CC. Surgical management of primary hyperparathyroidism: state of the art. Surg Clin North Am 2009; 89: 1205-25.

4. Grant CS, Thompson G, Farley D, van Heerden J. Primary hyperparathyroidism surgical management since the introduction of minimally invasive parathyroidectomy: Mayo Clinic experience. Arch Surg 2005; 140: 472-8.

5. Candell L, Campbell MJ, Shen WT, Gosnell JE, Clark OH, Duh QY. Ultrasound-guidedmethylenebluedyeinjectionforparathyroidloc alization in thereoperativeneck. World J Surg 2014; 38: 88-91.

6. Grant CS, van Heerden JA, Charboneau JW, James EM, Reading CC. Clinical management of persistent and / or recurrent primary hyperparathyroidism. World J Surg 1986; 10: 555-65.

7. Shen W, Duren M, Morita E, Higgens C, Duh Q-Y, Siperstein $A E$, et al. Reoperation for persistent or recurrent primary hyperparathyroidism. Arch Surg 1996; 131: 861-9.

8. Sociedade Brasileira de Endocrinologia e Metabologia, Bandeira F, Griz L, Chaves N, Carvalho NC, Borges LM, et al. Diagnosis and management of primary hyperparathyroidism-a scientific statement from the Department of Bone Metabolism, the Brazilian Society for Endocrinology and Metabolism. Arq Bras Endocrinol Metabol 2013; 57: 406-24.

9. Ryan WR, Orloff LA. Intraoperative tumor localization with surgeon performed ultrasound-guided needle dye injection. Laryngoscope 2011; 121: 1651-5.

10. Marcocci C, Bollerslev J, Khan AA, Shoback DM. Medical management of primary hyperparathyroidism: proceedings of thefourth International Workshop on the Management of Asymptomatic Primary Hyperparathyroidism. J Clin Endocrinol Metab 2014; 99: 3607-18.

11. Ilgan S, Ozbas S, Bilezikci B, Sengezer T, Aydin OU, Gursoy A, et al. Radioguided occult lesion localization for minimally invasive parathyroidectomy: technical consideration and feasibility. Nucl Med Commun 2014; 35: 1167-74.

12. Soyder A, Ünübol M, Ömürlü İK, Güney E, Özbaş S. Minimally invasive parathyroidectomy without using intraoperative parathyroid hormone monitoring or gamma probe. Ulusal Cerrahi Derg 2015; 31: 9-14.

13. Keereweer S, Kerrebijn JD, van Driel PB, Xie B, Kaijzel EL, Snoeks $\mathrm{TJ}$, et al. Optical image-guided surgery where do we stand? Mol Imaging Biol 2011; 13: 199-207.

14. Marcocci C, Mazzeo S, Bruno-Bossio G, Picone A, Vignali E, Ciampi $M$, et al. Preoperative localization of suspicious parathyroid adenomas by assay of parathyroid hormone in needle aspirates. Eur J Endocrinol 1998; 139: 72-7.

15. Erbil Y, Salmaslioğlu A, Kabul E, Işsever H, Tunaci M, Adalet I, et al. Use of preoperative parathyroid fine-needle aspiration and parathormone assay in the primary hyperparathyroidism with concomitant thyroid nodules. Am J Surg 2007; 193: 665-71.

16. Van der Vorst JR, Schaafsma BE, Verbeek FP, Swijnenburg RJ, Tummers $Q R$, Hutteman $M$, et al. Intraoperative near-infrared fluorescence imaging of parathyroid adenomas with use of low dose methylene blue. Head Neck 2014; 36: 853-8.

17. Bewick J, Pfleiderer A. Thevalueand role of low dose methylene blue in the surgical management of hyperparathyroidism. Ann R Coll Surg Engl 2014; 96: 526-9.

18. Derom A, Wallaert P, Janzing $H$, Van den Brande F, Derom F.Intraoperative identification of parathyroids by means of methylene blue. Acta Chir Belg 1994; 94: 97-100.

19. Kendrick ML, Charboneau JW, Curlee KJ, van Heerden JA, Farley DR. Risk of parathyromatosis after fine-needle aspiration. Am Surg 2001; 67: 290-4.

20. Giusti M, Dolcino M, Vera L, Ghiara C, Massaro F, Fazzuoli L, et al. Institutional experience of PTH evaluation on fine-needle washing after aspiration biopsy to locate hyperfunctioning parathyroid tissue. J Zhejiang Univ Sci 2009; 10: 323-30.

21. Shane E. Clinical review 122. Parathyroid carcinoma. J Clin Endocrinol Metab 2001; 86: 485-93.

22. Ünübol $M$, Güney $E$, Soyder $A$, Özbaş $S$, Erkuş $M$. A rare malignancy in the elderly patient: Parathyroid Carcinoma. Turkish J Geriatrics 2012; 15: 215-8.

23. Schantz A, Castleman B. Parathyroid carcinoma: A study of 70 cases. Cancer 1973; 31: 600-5. 